\title{
Persepsi Orang Tua Terhadap Lembaga Pendidikan Islam (Studi pada Masyarakat Tolaki di Kelurahan Bungguosu)
}

\section{Sabdah}

Fakultas Keguruan dan Ilmu Pendidikan, Universitas Lakidende Email: sabdah.unilaki@gmail.com

\begin{abstract}
Abstrak
Artikel ini bertujuan menggambarkan persepsi orang tua terhadap lembaga pendidikan Islam, yang mencakup tiga aspek yaitu: 1) sikap orang tua terhadap lembaga pendidikan Islam;2) motivasi orang tua menyekolahkan anak pada lembaga pendidikan Islam; 3) harapan orang tua terhadap lembaga pendidikan Islam. Penelitian dilakukan para masyarakat Tolaki di Kelurahan Bungguosu, secara kualitatif dengan pendekatan naratif, dimana pengumpulan data menggunakan teknik observasi, wawancara dan studi dokumentasi. Analisis data dilakukan secara bertahap, mulai dari pengumpulan data, reduksi data, penyajian data, hingga penarikan kesimpulan. Hasil penelitian menunjukan bahwa Persepsi masyarakat terhadap lembaga pendidikan Islam sangat beragam. Hal ini didasari oleh sikap, motivasi, dan harapan mereka pada lembaga pendidikan Islam. Rendahnya kepercayaan masyarakat pada lembaga pendidikan Islam adalah menunjukkan sikap mereka yang lebih menyukai lembaga pendidikan umum. Pemilihan lembaga pendidikan Islam masih didasari oleh faktor ekonomi, agama, dan keluarga. Harapan orang tua yang menyekolahkan anak pada lembaga pendidikan Islam lebih pada aspek religious, moral, dan pembentukan karakter. Oleh karenanya, orang tua memiliki kecenderungan lebih besar memilih sekolah umum. Implikasi dari kajian ini penulis mengajukan saran-saran sebagai berikut : 1) perlunya adaptasi teknologi terbaru pada lembaga pendidikan Islam; 2) perbaikan praktik kepemimpinan pada lembaga pendidikan Islam; 3) memulai menerapkan perencanaan strategis pada lembaga pendidikan Islam; dan 4) peningkatan akreditas.
\end{abstract}

\section{Kata Kunci: Persepsi, Madrasah, Pesantren, Sekolah Islam}




\title{
Parents' Perception of Islamic Educational Institutions (Study on the Tolaki Community in Bungguosu Village)
}

\begin{abstract}
This article aims to describe parents' perceptions of Islamic educational institutions, which includes three aspects, namely: 1) parents' attitudes towards Islamic educational institutions; 2) the motivation of parents to send their children to Islamic educational institutions; 3) parents' expectations of Islamic educational institutions. The research was conducted by the Tolaki community in Bungguosu Village, qualitatively with a narrative approach, where data collection used observation, interviews and documentation studies. Data analysis was carried out in stages, starting from data collection, data reduction, data presentation, to drawing conclusions. The results of the study show that public perceptions of Islamic educational institutions are very diverse. This is based on their attitudes, motivations, and expectations in Islamic educational institutions. The low level of public trust in Islamic educational institutions is an indication of the attitude of those who prefer public education institutions. The selection of Islamic educational institutions is still based on economic, religious, and family factors. The expectations of parents who send their children to Islamic educational institutions are more on religious, moral, and character building aspects. Therefore, parents have a greater tendency to choose public schools. The implication of this study is that the authors propose the following suggestions: 1) the need for adaptation of the latest technology in Islamic educational institutions; 2) improvement of leadership practices in Islamic educational institutions; 3) start implementing strategic planning in Islamic educational institutions; and 4) increase in accreditation.
\end{abstract}

Keywords: Perception, Madrasah, Pesantren, Islamic School 


\section{Pendahuluan}

Secara umum, proses pendidikan anak masih berada dalam kendali keluarga, terutama kedua orang tua. Hal ini tampak pula dalam pemilihan sekolah tempat seorang anak akan menempuh pendidikan. Kondisi kejiwaan anak yang belum stabil mengharuskan orang tua mengambil peran dominan dalam menentukan arah pendidikan seorang anak. Situasi ini dianggap sebagai bagian dari perhatian orang tua terhadap pendidikan anak, yang mana berbagai upaya penciptaan suasana edukatif di rumah mesti terkoneksi dengan lingkungan sekolah. Demikian pula suasana keagamaan yang tercipta di lingkungan keluarga diharapkan seiring sejalan dengan iklim sekolah (Dedih, Zakiyah \& Melina, 2019).

Pemilihan sekolah oleh orang tua bagi anak-anak mereka, terutama memilih sekolah agama, dapat dipengaruhi oleh berbagai faktor psikologis orang tua, misalnya: motivasi, persepsi, minat, pengalaman masa lalu, ataupun harapan. Riset sebelumnya menunjukkan bahwa pemilihan sekolah berbasis Islam didasari oleh pandangan bahwa sekolah berbasis Islam adalah sekolah yang memiliki porsi pendidikan agama lebih banyak dibanding sekolah umum, bernuansa Islami, sehingga dapat mendidik karakter anak. Motivasi menyekolahkan anak ke sekolah Islam dapat bersifat instrinsik yaitu anggapan bahwa melalui sekolah Islam anak-anak dapat menjadi pribadi yang shaleh, memahami dasar-dasar ajaran Islam, taat beribadah, pandai mengaji, dan memiliki akhlak mulia. Secara ekstrinsik, pemilihan sekolah Islam didasari alasan lebih besarnya porsi pendidikan agama dibanding sekolah umum. Alasannya lainnya adalah kurikulum, visi, misi dan tujuan yang sejalan dengan persepsi orang tua (Vitasari, 2017).

Harapan orang tua ketika menyekolahkan anak mereka pada sekolah Islam umumnya dilandasi oleh impian-impian ideal tentang generasi mereka misalnya: penguatan moral atau akhlak, dan memahami kitab suci Al-Qur'an untuk mendapatkan pengetahuan keagamaan yang memadai. Meskipun demikian, orang tua juga memerhatikan sekolah Islam yang layak dari segi profil dan tampilan fisik misalnya: kurikulum yang diterapkan, visi dan misi, sarana prasarana, prestasi dan biaya pendidikan (Isnaini \& Shobahiya, 2017). Artinya, disamping keinginan agar anak memiliki pengetahuan keagamaan yang baik, orang tua juga menilai kemampuan sekolah 
tersebut untuk memenuhi kebutuhan peserta didik, termasuk kewajaran biaya pendidikan yang diberlakukan.

Berdasarkan paparan di atas, kajian ini melalukan penelusuran pada orang tua di Kelurahan Bungguosu yang memilih sekolah Islam bagi anak-anak mereka. Faktanya, di Kabupaten Konawe saat ini memiliki lembaga pendidikan Islam (madrasah/pesantren/sekolah Islam) yang menjadi destinasi pendidikan keagamaan masyarakat. Dapat disebutkan disini beberapa sekolah Islam yang menjadi pilihan orang tua di Kelurahan Bungguosu untuk menyekolahkan anak-anak mereka yaitu: Madrasah Tsanawiyah Negeri Wawotobi, Madrasah Aliyah Al-Ikhlas Wawotobi, Pondok Pesantren Annur Azzubaidi, SDIT Asy-Syamil, SMPIT Asy-Syamil.

Meskipun pemilihan sekolah Islam oleh orang tua di Kelurahan Bungguosu telah tersebar pada sekolah-sekolah di atas, namun dari segi kuantitas jumlah ini masih sangat rendah dibandingkan dengan orang tua yang menyekolahkan anak pada sekolah umum. Kondisi ini menunjukkan bahwa lembaga pendidikan Islam masih menjadi pilihan kedua karena dianggap memiliki mutu yang lebih rendah dari sekolah umum. Selain itu, dari segi ekonomi memasukkan anak ke pesantren ternyata tidak mudah karena biaya masuk lebih besar dibanding sekolah negeri. Kehadiran sekolah Islam yang diselenggarakan secara full day belum dianggap dapat mensejajarkan diri pada aspek mutu, sebaliknya kesan sebagai "sekolah mahal" lebih nampak dalam pandangan masyarakat.

Kondisi faktual di atas, jika dikaitkan dengan sejarah islamisasi masyarakat Tolaki, tentu belum sesuai harapan. Sebagaimana diketahui bahwa Islam telah masuk ke bumi orang Tolaki sejak raja Tebawo (Melamba, 2013), yang mencapai puncaknya pada masa raja Lakidende II pada abad XVI yang secara resmi menjadikan Islam sebagai agama kerajaan (Alim, Badarwan \& Syahrul, 2020). Sebagai akibat dijadikannya Islam sebagai agama kerajaan Konawe, Raja Lakidende II mengeluarkan beberapa maklumat seperti: pengucapan syahadat, pembangunan masjid di setiap kampung, khitan, berhenti makan babi, menikah secara Islam, dan penguburan secara Islam (Syahrul, 2017). Maklumat tersebut cukup secara berlaku secara efektif ke seluruh wilayah kerajaan Konawe, dilakukan dari generasi ke generasi, sehingga praktiknya masih nampak dalam kehidupan kekinian. Efektifitas dari maklumat ini juga dapat dilihat dengan populasi Islam yang sangat dominan 
pada masyarakat Tolaki. Berdasarkan data kementerian dalam negeri tahun 2020 jumlah pemeluk Islam di Konawe yang mencapai 93,62\%, dimana Konawe menjadi salah wilayah hunian orang Tolaki (Wikipedia, 2021). Meskipun ada pendapat bahwa orang Tolaki pernah menurun populasinya pada masa penyiaran agama Kristen yang kemudian berubah ketika gerakan DI/TII masuk di Konawe, sehingga menggiring kembali orang Tolaki memeluk Islam (Sonaru, 2015).

Gerakan melanjutkan tradisi Islam pada generasi muda, bahkan sejak usia dini, telah dilakukan oleh para penyuluh keagamaan di berbagai perkampungan orang Tolaki melalui Taman Pendidikan Al-Qur'an. Para penyuluh agama ini bergerak dalam pengentasan buta baca Al-Qur'an, salah satunya berlangsung di Kelurahan Bungguosu. Peran-peran yang dilakukan para penyuluh agama tersebut menjadi penjaga tradisi Islam. Disadari bahwa Islam akan survive pada suatu komunitas jika pendidikan Al-Qur'an berlangsung secara terusmenerus dalam berbagai bentuknya (Sabdah \& Sastramayani, 2018). Dalam konteks inilah ikhtiar mendidik Al-Qur'an pada masyarakat Islam harus dikembangkan dengan cara mendorong peningkatan anakanak bersekolah pada lembaga pendidikan Islam. Pada sekolahsekolah formal tersebut tidak hanya mengajarkan baca tulis Al-Qur'an tetapi juga berbagai aspek ajaran-ajaran Islam.

Pemilihan sekolah bagi anak sangat ditentukan oleh persepsi orang tua, baik positif maupun negatif. Persepsi positif lahir karena orang tua merasakan hal-hal baik dalam proses penyelenggaraan pendidikan. Sebaliknya, persepsi negatif bermula dari ketidakpuasan orang tua terhadap berbagai layanan yang diberikan lembaga pendidikan. Sesungguhnya persepsi tidak berdiri sendiri, variabel penyertanya adalah motivasi. Orang memiliki beragama motivasi dalam menyekolahkan anak pada lembaga pendidikan Islam di antaranya: motif idiologis, motif edukasi, motif strukturalis, motif ekonomi, dan motif pragmatis (Erdiyanti, 2018).

Melihat paparan di atas, memilih lembaga pendidikan Islam mestinya menjadi langkah penting yang harus dilakukan oleh masyarakat Tolaki. Karna faktanya jumlah anak usia sekolah yang belajar pada lembaga pendidikan Islam, terutama di Kelurahan Bungguosu, sangat kecil sebagaimana terlihat pada tabel 1. Pada tabel 1 tersebut terlihat bahwa peserta didik yang bersekolah di madrasah, pesantren, sekolah Islam dan perguruan tinggi Islam berjumlah 9 
orang. Artinya, terjadi kesenjangan antara sisi sejarah orang Tolaki yang telah memeluk Islam sejak abad XVI dengan realitas kekinian masyarakat Tolaki di Kelurahan Bungguosu yang memiliki kecenderungan yang rendah terhadap lembaga pendidikan Islam.

Tabel 1. Jumlah Anak Yang Bersekolah pada Lembaga Pendidikan Islam

\begin{tabular}{|c|l|c|}
\hline No & Lembaga Pendidikan Islam & Jumlah \\
\hline 1 & Madrasah & 2 \\
\hline 2 & Pesantren & 3 \\
\hline 3 & Sekolah Islam & 3 \\
\hline 4 & Perguruan Tinggi Islam & 1 \\
\hline & Jumlah & $\mathbf{9}$ \\
\hline
\end{tabular}

Sumber: hasil observasi di Kelurahan Bungguosu, 2021

Berdasarkan paparan di atas, kajian ini mencoba mendalami variabel-variabel yang memengaruhi orang tua dalam memilih lembaga pendidikan Islam bagi anak mereka. Kajian berfokus pada persepsi orang tua yang mencakup: sikap, motivasi, dan harapan terhadap lembaga pendidikan Islam.

\section{Metode}

Permasalahan penelitian dikaji secara kualitatif dengan menggunakan pendekatan naratif, yaitu studi berfokus pada narasi atau deskripsi tentang serangkaian peristiwa terkait pengalaman manusia (Creswell \& Poth, 2016). Dalam konteks artikel ini, penggunaan pendekatan naratif diartikan sebagai proses mendalami peristiwa-peristiwa yang dialami oleh orang tua peserta didik di Kelurahan Bungguosu tentang pengalaman mereka dalam memilih lembaga pendidikan Islam sebagai tempat belajar anak-anak mereka.

Kelurahan Bungguosu menjadi tempat penelitian ini, berada di wilayah administrative Kecamatan Konawe Kabupaten Konawe, Provinsi Sulawesi Tenggara. Dari segi keagamaan, masyarakat di Kelurahan Bungguosu 100\% memeluk agama Islam, dan secara social menjalankan berbagai tradisi Islam seperti: maulid, tahun baru Islam, khataman Al-Qur'an, tahlilan, qunut, dan yasinan. Di kelurahan ini juga terdapat dua masjid yang dibangun secara gotong royong oleh masyarakat. Meskipun demikian, dalam konteks pemilihan lembaga pendidikan bagi anak-anak usia sekolah, terlihat kecenderungan yang rendah pada orang dalam memiliki lembaga pendidikan Islam. 
Dengan latar demikian, kajian artikel ini mendeskripsikan faktorfaktor yang memengaruhi orang tua dalam mengekolahkan anak pada lembaga pendidikan Islam.

Penelitian yang dilakukan selama 5 (lima) bulan (21 Maret 21 Agustus 2021) menghasilkan berbagai informasi, baik data primer dan data sekunder. Data primer diperoleh melalui observasi dan wawancara. Sedangkan data sekunder diperoleh melalui pembacaan dokumen-dokumen relevan misalnya jurnal ilmiah, dan data kependudukan. Dalam proses observasi, penulis berperan sebagai insider karena penulis adalah warga setempat dan juga mengalami peristiwa memilih lembaga pendidikan Islam bagi anak. Jadi, peneliti menjalankan pengamatan partisipatif. Wawancara dilakukan secara terbuka, tidak terstruktur, karena dilakukan secara alamiah yaitu pada interaksi keseharian dengan masyarakat. Studi dokumentasi dilakukan dengan membaca profil masyarakat di kantor kelurahan Bungguosu untuk mendapatkan gambaran utuh tentang kondisi demografis.

Data yang terkumpul dianalisi dengan menggunakan kerangka yang dikembang oleh Miles \& Huberman. Analisis ini dilakukan mulai dari tahap pengumpulan data, reduksi data, penyajian data, dan penarikan kesimpulan (Miles \& Huberman, 1994). Analisis pada tahap pengumpulan data mencakup pemilihan topik-topik untuk diobservasi, diwawancara, dan dipelajari dokumennya. Pada tahap reduksi data, peneliti memilah berbagai data yang terkumpul selanjut dipilih data yang relevan dan dibutuhkan untuk menjawab pertanyaan penelitian. Data yang telah direduksi kemudian disajikan dalam bentuk narasi, bagan, dan tabel. Sebelum mengambil kesimpulan akhir, peneliti melalukan verifikasi data melalui member check, membaca kembali naskah hasil penelitian secara seksama, dan kembali ke lapangan untuk memastikan kesesuaian catatan dengan kondisi sesungguhnya.

\section{Hasil Penelitian}

\section{A. Sikap Orang Tua Tentang Lembaga Pendidikan Islam}

Secara umum, masyarakat di Kelurahan Bungguosu semakin menyadari pentingnya pendidikan demi kebaikan generasi di masa mendatang. Di masa sebelumnya, sering dijumpai atau didengar dalam percakapan sehari-hari terkait pesimisme terhadap pendidikan dan persekolahan, misalnya dalam ungkapan "tidak perlu sekolah, sudah banyak pegawai" atau "tidak perlu sekolah, sudah banyak guru". Ungkapan-ungkapan tersebut menggambarkan pesimisme terhadap 
pendidikan atau menganggap sekolah tidak penting, tidak memberi dampak besar dalam kehidupan. Adapula ungkapan "sekolah tidak perlu tinggi-tinggi, yang penting bisa membaca dan menulis". Artinya sudah ada kemauan untuk sekolah tetapi hanya pada tingkat dasar atau sekolah dasar saja.

Seiring perkembangan zaman, interaksi masyarakat dengan komunitas lainnya semakin intens terjalin, yang secara perlahan memengaruhi pandangan dan penilaian masyarakat tentang pendidikan. Sebagai contoh, pada tahun 1990-an kegiatan-kegiatan Kuliah Kerja Nyata (KKN) yang dilaksanakan oleh mahasiswa dari beberapa perguruan tinggi di Sulawesi Tenggara antara lain: Universitas Sulawesi Tenggara, Universitas Halu Oleo dan IAIN Alauddin Kendari sangat memengaruhi penilaian masyarakat tentang pendidikan. Karena mereka melihat bahwa mahasiswa yang berKKN dapat memainkan berbagai peran ketika di masyarakat. Melalui mahasiswa, masyarakat mendapat pengetahuan dan pengalaman baru, serta relasi baru.

Meskipun terjadi lonjakan partisipasi pendidikan di Kelurahan Bungguosu, akan tetapi sebagian besar menyasar lembaga pendidikan umum seperti SMP, SMA atau SMEA/SMK. Di masa lalu, musim gandrung terhadap SMK pernah dirasakan oleh masyarakat Konawe karena daya tarik yang diperkenalkan oleh SMEA Unaaha, sehingga tamatan SMP berbondong-bondong dan berlomba masuk ke sekolah tersebut. Tetapi kondisi ini tidak berlangsung lama, karena faktanya harapan-harapan yang ditawarkan sekolah tersebut tidak mudah diwujudkan dalam kenyataan. Orientasi kerja yang ditawarkan dalam propaganda ternyata tidak signifikan pembuktiannya ketika para lulusan memasuki masa kerja.

Fakta yang menarik adalah lembaga pendidikan Islam selalu menjadi pilihan terakhir. Misalnya ketika tidak diterima dalam seleksi masuk di SMA Negeri, maka jadi madrasah sebagai pilihan. Ataupun keberadaan Madrasah Diniyah Awaliyah (MDA) yang juga tidak cukup memberi daya tarik bagi masyarakat sehingga berjalan stagnan, munduk, dan akhirnya bubar. Demikian pula anak-anak yang bersekolah di Madrasah Tsanawiyah Negeri (MTsN) Wawotobi, jika diperhatikan terbagi dalam dua karakteristik: pertama, orang tua memiliki latar belakang pendidikan agama, misalnya PGA (pendidikan guru agama). Kedua, kalangan keluarga religious yang berprofesi pedagang. Sedangkan yang memilih perguruan tinggi Islam 
umumnya karena kesinambungan pendidikan sebelumnya, misalnya dari pesantren dan madrasah aliyah.

Fenomena rendahnya jumlah anak yang bersekolah pada lembaga pendidikan Islam pada masyarakat Bungguosu dapat dilihat sebagai perwujudan sikap individual orang tua. Jumlah pemeluk Islam yang 100\% ternyata tidak berbanding lurus dengan kesukaannya masyarakat terhadap lembaga pendidikan Islam seperti: madrasah, pesantren, dan sekolah Islam, ataupu perguruan tinggi Islam. Data menunjukkan bahwa rasa suka orang tua di Kelurahan Bungguosu terhadap lembaga pendidikan Islam sangat rendah. Pada saat yang sama rasa suka terhadap sekolah umum sangat tinggi.

Kemapanan yang ditunjukkan sekolah-sekolah umum terutama yang berstatus negeri menjadi daya sedot yang cukup kuat. Misalnya, bangunan yang lebih bagus dari madrasah, bahan pustaka yang tersedia secara memadai, jumlah guru yang terpenuhi rasionya, penataan lingkungan sekolah, dan akreditasi. Persoalan akreditasi menjadi medan magnet yang cukup kuat karena efeknya ketika lulusan akan mendaftar keperguruan tinggi, terutama terkait proses mendapatkan beasiswa. Lulusan SMA dengan akreditasi A memiliki kuota yang lebih tinggi dalam pengusulan beasiswa dibanding sekolah-sekolah sederajat dengan peringkat akreditasi di bawahnya. Faktanya, madrasah Aliyah Al-Ikhlas Wawotobi masih memiliki peringkat akreditasi B.

Kehadiran sekolah Islam yang menjalankan system Full Day sebenarnya cukup menarik. SDIT dan SMPIT Asy-Syamil Unaaha adalah sekolah Islam yang cukup memberi daya tarik tersendiri. Hanya saja, masyarakat melihat sekolah tersebut tidak sesuai dengan kondisi ekonomi keluarga. Meskipun masyarakat menilai bahwa sekolah Islam full day tersebut baik dan menyatakan suka, tetapi hal itu belum sampai pada tindakan memasukkan anak mereka ke sekolah tersebut.

Berbagai aspek perbandingan yang dilakukan oleh masyarakat terhadap lembaga pendidikan Islam dengan sekolah umum terakumulasi menjadi sikap menyukai dan tidak menyukai lembaga pendidikan Islam. Fakta ini sesungguhnya menunjukkan bahwa secara internal lembaga pendidikan Islam sangat mendesak untuk melakukan pembenahan. 


\section{B. Motivasi Menyekolahkan Anak Pada Lembaga Pendidikan Islam}

Pada bagian ini akan dideskripsikan faktor-faktor yang memengaruhi pilihan orang tua menyekolahkan anak pada lembaga pendidikan Islam. Hasil penelitian menunjukkan bahwa ada 3 (tiga) faktor yang sangat menonjol yaitu: 1) faktor ekonomi; 2) faktor agama; dan 3) faktor keluarga. Tiga tema ini yang menjadi simpul atas berbagai fakta terkait pemilihan lembaga pendidikan Islam oleh orang tua dalam menyekolahkan anak mereka.

\section{B1. Faktor Ekonomi}

Kondisi ekonomi keluarga yang hanya dapat memenuhi kebutuhan sehari-hari cukup memengaruhi pilihan lembaga pendidikan. Jika dibandingkan, biaya pendidikan antara SMA Negeri dengan Madrasah Aliyah Swasta Al-Ikhlas Wawotobi cukup jauh, dimana SMA Negeri memiliki tagihan biaya pendidikan yang lebih tinggi. Karenanya, beberapa anak akhirnya memilih bersekolah di Madrasah Aliyah Swasta Al-Ikhlas Wawotobi. Kasus ini cukup spesifik karena hanya terjadi pada lulusan SMP atau sederajat yang akan melanjutkan pendidikan di SMA atau sederajat. Berbeda kondisinya dengan anak-anak tamatan SD yang akan melanjutkan pendidikan pada jenjang SMP atau sederajat yang tidak berkaitan dengan faktor ekonomi.

Orang tua yang menyekolahkan anak mereka di Madrasah Aliyah Wawotobi pada umumnya berlatar belakang ekonomi yang tidak berkecukupan. Hal lain yang juga berkaitan dengan biaya pendidikan adalah sedikitnya kegiatan-kegiatan ekstra di madrasah sehingga pengeluaran untuk kegiatan tambahan sekolah tersebut cukup kecil.

Berbeda kasusnya pada orang tua yang menyekolahkan anak di sekolah Islam yang diselenggarakan secara full day, dengan kondisi ekonomi yang lebih baik. Misalnya di SDIT Asy-Syamil dan di SMPIT Asy-Syamil (kedua sekolah ini berada di bawah yayasan yang sama) dengan biaya pendidikan yang cukup tinggi, melampaui sekolah-sekolah negeri. Sebagai gambaran, biaya masuk sekolah tersebut mencapai $6-7$ juta. Sedangkan SPP perbulan adalah Rp. 300.000 ditambah biaya catering Rp. 300.000 , sehingga biaya tetap perbulan adalah Rp.600.000. Belum lagi biaya tidak tetap pada kegiatan ekstrakurikuler dengan intensitas yang cukup tinggi. Artinya, 
orang tua menyekolahkan anak mereka di sekolah Islam full day tersebut berasal dari kalangan ekonomi menengah.

Kasus yang sama dialami orang tua yang memilih menyekolahkan anak di pondok pesantren, misalnya yang paling dekat di Pondok Pesantren Annur Azzubaidi. Biaya pendidikannya relatif tinggi karena santri membayar biaya pendidikan dalam dua kategori, yaitu biaya sekolah formal (madrasah pesantren) dan kegiatan pondok. Demikian pula kegiatan tambahan santri yang berlangsung selama 24 jam, membutuhkan biaya ekstra. Jadi, meskipun pondok pesantren kadang dianggap sekolah desa tetapi dari segi biaya cukup tinggi. Artinya, orang tua yang menyekolahkan anak di pondok pesantren berasal dari kalangan ekonomi menengah, yang berprofesi pedagang dan pegawai negeri sipil (PNS).

Kasus yang unik adalah pada keputusan seorang anak untuk melanjutkan pendidikan ke perguruan tinggi Islam, yang tidak lagi murni merupakan keputusan orang tua. Situasi ini dapat dilihat dalam dua aspek: 1) orang tua yang mampu secara ekonomi akan menggunakan pendekatan rasional kepada anak yang akan melanjutkan pendidikan. Misalnya, menyarankan agar linear dengan sekolah sebelumnya (madrasah atau pesantren). Hal ini memang terbukti, bahwa anak-anak di Kelurahan Bungguosu yang melanjutkan pendidikan ke IAIN Kendari adalah tamatan madrasah dan pondok pesantren. 2) orang tua yang menyerahkan sepenuhnya keputusan kepada anak, kuliah atau berhenti, karena kondisi ekonomi yang tidak mendukung. Situasi ini dialami oleh anak tamatan madrasah atau sekolah umum yang ingin kuliah tetapi kondisi ekonomi keluarga tidak mendukung. Upaya yang dilakukan adalah mendorong anak belajar keras agar bisa masuk peringkat 3 atau 5 besar ketika pelulusan di madrasah atau SMA. Harapannya adalah mendapatkan beasiswa pendidikan untuk mahasiswa miskin berprestasi atau Bidikmisi. Program Bidikmisi mensyaratkan peringkat 3 besar untuk sekolah/madrasah berakreditasi $\mathrm{B}$ dan perikat 5 besar untuk sekolah/madrasah berakreditasi A. Jika tidak terjaring pada program Bidikmisi, calon mahasiswa dapat bermohon untuk dapat diberikan kebijakan pemotongan SPP yang memang ada, seperti di IAIN Kendari.

Fakta-fakta di atas menggambarkan bahwa persoalan ekonomi masih menjadi aspek krusial dalam pendidikan di Kelurahan Bungguosu. Termasuk dalam memilih menyekolahkan anak pada 
lembaga pendidikan Islam. Meskipun demikian, nampaknya mulai tumbuh kesadaran terutama pada tamatan madrasah Aliyah/SMA untuk terus memiliki harapan menjejak perguruan tinggi melalui jalur prestasi. Karenanya, mereka yang telah merencanakan untuk ke perguruan tinggi Islam akan menyiapkan diri lebih awal, belajar keras, agar dapat masuk peringkat sesuai yang dipersyaratkan.

\section{B2. Faktor Keagamaan}

Faktor agama mendominasi ketika orang tua memilih Madrasah Tsanawiyah, Pesantren, dan Sekolah Islam. Orang tua yang memilih lembaga pendidikan Islam tersebut pada umumnya didorong oleh semangat keagamaan. Misalnya, orang tua berkeinginan memberikan dasar-dasar keagamaan yang kuat pada anaknya agar memiliki karakter yang kuat. Para orang tua yang memiliki keterbatasan dalam membiayai pendidikan anak akan memilih madrasah tsanawiyah. Karena pesantren maupun sekolah Islam memiliki tarif pendidikan yang lebih tinggi dibanding madrasah tsanawiyah. Alasan yang sama juga berlaku ketika memilih madrasah Aliyah, yaitu biaya pendidikan yang lebih rendah dibandingkan dengan pesantren.

Orang tua berkeinginan agar anak-anak mereka dapat memahami ilmu-ilmu dasar keagamaan seperti baca tulis Al-Qur'an, mampu melaksanakan ibadah-ibadah utama sesuai rukun Islam misalnya shalat, puasa, zakat, dan haji. Mereka berkeyakinan bahwa dasar-dasar keagamaan tersebut dapat menjadi bekal berharga bagi anak-anak mereka ketika dewasa. Ada ungkapan orang tua di Kelurahan Bungguosu terkait hal ini yaitu "sejauh-jauhnya seseorang tersesat tetapi jika pernah mempelajari agama di masa kecil maka suatu saat akan kembali baik". Dalam konteks ini terlihat bahwa pemilihan lembaga pendidikan Islam oleh orang tua adalah upaya membentengi anak-anak mereka sejak dini.

Sedangkan dalam konteks pemilihan perguruan tinggi Islam bagi lulusan madrasah aliyah/SMA, alasannya adalah keinginan mendalami lebih lanjut ilmu-ilmu keagamaan bagi yang lulusan madrasah atau pondok pesantren. Sedangkan lulusan SMA yang akan memilih program studi yang dianggap lebih longgar terhadap penguasaan ilmu-ilmu alat keagamaan. Yang dimaksud ilmu alat adalah pemahaman bahasa Arab bagi yang memilih program studi Ilmu Al-Qur'an dan Tafsir (IQT). Berbagai program studi yang 
disebut longgar terhadap ilmu alat keagamaan telah tersedia di IAIN Kendari.

Fakta-fakta di atas menunjukkan bahwa motif keagamaan orang tua memiliki kadar yang variatif, atau memiliki kategori tertentu terkait pilihan menyekolahkan anak-anak mereka di lembaga pendidikan Islam. Kategorinya adalah: pertama, orang tua yang menyekolahkan anak-anaknya ke sekolah agama karena keterkaitan dengan pendidikan orang tuanya ataupun tingginya keterlibatan orang tua dalam kegiatan keagamaan. Selain itu, kesinambungan pendidikan si anak dengan jenjang pendidikan sebelumnya. Kedua, orang tua yang menyekolahkan anaknya pada lembaga pendidikan Islam tetapi memilih program studi yang lebih seimbang antara pengetahuan agama dan umum.

\section{B3. Faktor Keluarga}

Masuknya seorang anak ke lembaga pendidikan Islam juga dipengaruhi oleh lingkungan keluarga. Penelitian ini menemukan bahwa anak-anak di Kelurahan Bungguosu yang sekolah di madrasah, pesantren, sekolah, dan perguruan tinggi memiliki keluarga yang dengan iklim keagamaan yang kuat. Biasanya orang tua mereka adalah tokoh agama, memiliki latar belakang pendidikan keagamaan, juga aktif terlibat dalam kegiatan-kegiatan keagamaan.

Faktor keluarga ini tidak hanya memiliki efek pada intern keluarga itu sendiri tetapi juga memengaruhi lingkungan mereka secara luas. Keberhasilan sebuah keluarga dalam menyekolahkan anak mereka pada lembaga pendidikan Islam membuat lingkungan sekitar keluarga tersebut tertarik untuk melakukan hal yang sama. Penelitian ini menemukan adanya pengaruh yang kuat dari suatu keluarga dalam menghidupkan tradisi keagamaan di Kelurahan Bungguosu.

Stigma keluarga "berpendidikan agama" adalah sesuatu yang biasa diberikan kepada suatu keluarga yang umumnya memilih sekolah agama untuk belajar. Stigma itu terkadang membawa konsekwensi dalam pergaulan sosial, misalnya keluarga berpendidikan agama lebih tertutup dan kaku karena mereka dibatasi oleh norma-norma agama. Akibatnya, jika salah satu dari anggota keluarga itu berperilaku di luar kewajaran, maka akibatnya adalah generalisasi terhadap seluruh anggota keluarga. Dalam kondisi demikian, kehidupan keluarga "berpendidikan agama" selalu berada dalam kehati-hatian yang tinggi. Justru ini pulalah yang mengakibatkan lahirnya stigma tertutup dan kaku tersebut. 


\section{Harapan Orang Tua pada Lembaga Pendidikan Islam}

Perkembangan zaman yang semakin cepat akibat revolusi teknologi informasi membuat sebagian orang tua menyadari perlunya pendidikan agama. Cara mereka melepaskan dahaga keagamaan dilakukan dengan mengikuti kelompok-kelompok keagamaan seperti Jama'ah tabligh, salafi, ataupun pada organisasi Islam mainstream seperti Nadhatul Ulama' (NU) dan Muhammadiyah. Cara itu dianggap cukup efektif untuk memberi suntikan pemahaman keagamaan mereka. Meskipun dalam beberapa kasus terlihat bahwa keikutsertaan mereka pada kelompok-kelompok keagamaan tertentu menyebabkan konflik, disebabkan merasa paling benar dari yang lain.

Paling penting diuraikan pada bagian ini adalah pendidikan agama bagi anak-anak usia sekolah. Efek dari keikutsertaan orang tua dalam kelompok-kelompok keagamaan (sebagaimana dijelaskan di atas) adalah kecenderungan yang cukup kuat menyekolahkan anak mereka ke madrasah, pesantren, dan sekolah Islam. Cara ini dianggap dapat melepaskan anak-anak mereka dari ketidaktahuan tentang agama sejak kecil. Dengan memasukkan anak-anak mereka pada lembaga pendidikan Islam, diharapkan di masa depan anak-anak tersebut akan menjadi pelopor kehidupan keagamaan di kampung mereka.

Generasi-generasi sebelumnya di Keluraha Bungguosu adalah contoh, bahwa dengan mengambil jalur pendidikan keagamaan mulai dari tingkat dasar sampai perguruan tinggi, mereka dapat menjadi pemantik tidak hanya kegiatan keagamaan tetapi berbagai kegiatan sosial kemasyarakatan. Hal ini turut membuka mata masyarakat bahwa jalur pendidikan keagamaan memiliki segmen pengabdian yang cukup luas. Keterampilan komunikasi yang dimiliki karena latihan di kampus maupun organisasi-organisasi kemahasiswaan adalah modal penting dalam menggerakkan masyarakat. Karenanya, orang tua saat ini memiliki harapan lebih ketika anak-anak mereka memilih lembaga pendidikan Islam.

\section{Pandangan Umum Orang Tua Tentang Mutu Lembaga Pendidikan Islam}

\section{D1. Pandangan terhadap Madrasah}

Meskipun telah banyak kemajuan dalam lembaga pendidikan Islam, termasuk alumninya yang mewarnai tidak hanya kegiatan keagamaan tetapi berbagai kegiatan sosial kemasyarakatan, akan tetapi lembaga pendidikan Islam dianggap masih belum setara dengan 
sekolah umum. Apalagi di masa lalu beberapa anak yang lulusan madrasah tsanawiyah negeri tidak diterima di SMA Negeri dengan adanya persyaratan Nilai Ebtanas Murni (NEM) minimal, sehingga memilih sekolah-sekolah swasta. Meskipun ada beberapa kasus menunjukkan bahwa ada jalan tidak resmi untuk dapat masuk ke SMA Negeri yang disebut "Letjend" atau lewat jendela. Cara-cara transaksional itulah yang ditempuh oleh orang tua yang benar-benar ngotot menyekolahkan anak-anak mereka ke SMA Negeri. Istilah lain yang artinya sama adalah "uang meja" atau "uang kursi". Praktik ini ternyata tidak hanya menyasar alumni madrasah tsanawiyah tetapi lulusan SMP/sederajat yang tidak mencapai standard NEM minimal untuk syarat masuk SMA Negeri.

Kasus-kasus yang terkait dengan sekolah agama di atas menjadi salah satu fakta yang selalu dikaitkan dengan pandangan orang tua di Kelurahan Bungguosu terhadap lembaga pendidikan Islam. Menurut mereka, salah satu penyebab ketertinggalan lembaga pendidikan Islam dari sekolah umum adalah kekurangan tenaga pendidikan dan kependidikan. Bahkan lembaga pendidikan Islam yang berstatus negeri pun masih belum menyamai ketersediaan SDM di sekolah umum. Kondisi demikian dianggap sebagai penyebabnya ketidakmampuan lembaga pendidikan Islam dalam mensejajarkan diri dengan sekolah umum.

Kondisi lebih parah ditujukan kepada lembaga pendidikan Islam yang berstatus swasta, terutama madrasah Aliyah Swasta. Menurut masyarakat, akibat keterbatasan tenaga pendidik maka siswasiswa di sekolah tersebut jarang belajar, akhirnya lebih banyak berkeliaran di luar. Artinya, kebutuhan anak-anak untuk belajar tidak terpenuhi, padahal setiap pagi mereka pamit dari rumah ke sekolah untuk belajar. Menyekolahkan anak mereka pada sekolah yang demikian dianggap sia-sia, hanya menghabiskan waktu, menghabiskan biaya, dan menghabiskan energi. Pada titik tertentu lahirlah pernyataan ekstrim "daripada ke sekolah tidak belajar lebih baik berhenti, bantu orang tuamu berkebun". Pernyataan ini seolah menggambarkan bahwa kondisi orang tua yang pesimis dan tidak percaya lembaga pendidikan Islam, terutama madrasah.

\section{D2. Pandangan Terhadap Pesantren}

Sebagaimana telah dijelaskan sebelumnya, biaya pendidikan di pondok pesantren cukup tinggi sehingga tidak banyak orang tua di Kelurahan Bungguosu yang membawa anak mereka ke pondok 
pesantren. Beberapa orang tua menyatakan ketertarikan untuk menyekolahkan anak-anak mereka di pondok pesantren tetapi tidak memiliki biaya yang cukup. Bagi mereka, sekolah agama yang baik itu di Pesantren karena guru-guru relatif tersedia, dan sistem asrama yang cukup terawasi.

Tidak hanya faktor ekonomi keluarga membuat orang tua di Kelurahan Bungguosu tidak dapat menyekolahkan anak-anak mereka di pondok pesanten. Faktor lain itu adalah ketidaksanggupan orang tua untuk melepaskan anak dalam waktu yang lama. Jadi ini adalah persoalan pemahaman dan mental yang belum terbangun pada para orang tua. Apalagi, sebagai orang kampung, keberadaan anak di lingkungan keluarga dapat meringankan beban pekerjaan tertentu. Sehingga akhir mereka memiliki sekolah yang menerapkan sistem half day, dimana anak bisa sekolah bolak-balik rumah dengan sekolah.

Hidup mondok bagi anak-anak belumlah menjadi kebiasaan di Kelurahan Bungguosu. Ketertarikan terhadap dunia pesantren sudah mulai ada, akan tetapi belum dominan karena alasan-alasan di atas. Beberapa anak yang dikirim orang tua mereka ke pondok pesantren telah menyelesaikan studi dan melanjutkan pendidikan ke perguruan tinggi. Namun hal itu tidak cukup menjadi pemicu bagi orang tua yang lain untuk mengirim anak-anak mereka di pondok pesantren.

\section{D3. Pandangan terhadap Sekolah Islam}

Sekolah Islam merupakan fenomena baru di Kelurahan Bungguosu, bahkan di Kabupaten Konawe. Selama ini, masyarakat menganggap bahwa yang dimaksud sekolah agama itu adalah madrasah dan pesantren. Kehadiran Sekolah Dasar Islam Terpadu (SDIT) Asy-Syamil dan Sekolah Menengah Pertama Islam Terpadu (SMPIT) Asy-Syamil telah membawa pengetahuan baru bagi masyarakat di Kelurahan Bungguosu tentang varian lain dari lembaga pendidikan Islam.

Model penyelenggaraan yang bersifat full day menjadi perhatian orang, tentang apa saja yang dilakukan peserta didik selama sehari di sekolah. Para orang tua selama hanya tahu sekolah dengan waktu belajar setengah hari (half day). Berbagai pertanyaan muncul terkait kondisi anak-anak misalnya: apakah anak tidak letih? Waktu dengan orang tua semakin berkurang, apa yang dilakukan guru, dan seterusnya. Belum lagi biaya pendidikan yang lebih tinggi melampaui lembaga pendidikan Islam lainnya, bahkan sekolah umum. Jika 
selama ini orang tua mengenal madrasah yang berbiaya murah, maka SDIT dan SMPIT memperlihatkan sebaliknya.

Bagi orang tua yang menyekolahkan anak mereka pada sekolah Islam tersebut, mereka menganggap hal ini sebagai jalan tengah karena tidak ke pesantren. Meskipun seharian di sekolah tetapi masih ada waktu anak-anak untuk bertemu keluarga. Dalam perkembangan SMPIT Asy-Syamil telah membuka sistem asrama, artinya mirip dengan pesantren, dimana santri mondok atau tidak lagi kembali kerumah orang tua. Namun ini bersifat pilihan, tergantung orang tua mau memondokkan anaknya atau seperti biasa bersekolah full day.

Bagi orang tua yang tidak menyekolahkan anaknya di sekolah Islam tersebut, menganggap sekolah tersebut adalah sekolah mahal, biasa disebut sekolah "elite" karena didatangi oleh kalangan masyarakat dengan kondisi ekonomi yang cukup baik. Kehadiran sekolah Islam ini juga menjadi penyeimbang opini bahwa semua lembaga pendidikan Islam terbelakang. Meskipun bersatus swasta, tetapi pamor sekolah Islam ini memberi gaung yang sangat besar dalam peta persekolahan di Kabupaten Konawe.

\section{D4. Pandangan terhadap Perguruan Tinggi Islam}

Bagi masyarakat di Kelurahan Bungguosu, perguruan tinggi Islam bukanlah sesuatu yang asing karena telah ada beberapa lulusan dari perguruan tinggi Islam, misalnya lulusan IAIN Alauddin Kendari, STAIN Kendari, dan saat ini menjadi IAIN Kendari. Selain, beberapa kali Kelurahan Bungguosu menerima kelompok mahasiswa dari perguruan tinggi Islam yang melakukan Kuliah Kerja Nyata (KKN). Kondisi ini sesungguhnya cukup membangun opini yang baik tentang perguruan islam di masyarakat. Hanya saja belum seirama dengan keinginan untuk menyekolahkan anak mereka ke IAIN atau UIN.

Akibat dari kurangnya anak-anak yang bersekolah agama mulai dari jenjang dasar, menengah, dan atas menyebabkan rendahnya pula yang ke perguruan tinggi Islam. Namun ada perkembangan yang menggembirakan seiring dengan terbukanya program studi umum di IAIN Kendari, yaitu mulai tertariknya anak-anak lulusan SMA Negeri ataupun swasta di Kelurahan Bungguosu untuk masuk ke perguruan tinggi Islam tersebut. Artinya, ada keinginan orang tua agar anaknya dapat kuliah di perguruan tinggi Islam tetapi pada saat yang sama juga memeroleh pengetahuan umum. Ini adalah pandangan masyarakat tentang perlunya keseimbangan pengetahuan agama dan umum. 
Berdasarkan paparan di atas, terlihat bahwa madrasah yang berstatus swasta berada pada posisi paling tersudutkan dalam pandangan masyarakat, misalnya tentang ketersediaan SDM dan anggapan sekolah yang rendah. SDM yang terbatas menyebabkan lembaga pendidikan tidak dapat berfungsi secara maksimal, terutama kegiatan pembelajaran sebagai inti kegiatan madrasah. Jika hal itu terus berlanjut maka yang menjadi korban adalah peserta didik karena hak-hak mereka untuk mendapatkan pembelajaran tidak diperoleh dengan baik. Akibatnya, orang tua mengalami kehilangan kepercayaan terhadap madrasah sehingga enggan untuk mengirimkan anak-anak mereka ke madrasah. Jika jumlah peserta didik kurang maka dana yang diterima juga akan kurang, misalnya dan BOS yang dihitung persiswa.

Kondisi ini berbeda dengan kehidupan pesantren yang memiliki mekanisme pertahanan diri yang kuat. Di samping biaya pendidikan yang lebih besar dari madrasah, pesantren memiliki usahausaha internal atau kewirausahaan yang menunjang berjalan roda organisasi pondok. Asatidz relatif tersedia dan selalu siap melaksanakan tugas setiap saat karena umumnya berdomisili di lingkungan pondok. Aspek-aspek yang bersifat materialistik relatif tidak mengganggu tugas mereka karena mereka memiliki ikatan yang kuat dengan pondok, memiliki usaha dan keterampilan yang dapat menghasilkan pendapatan. Status swasta pondok pesantren tidak jadi masalah, karena pada dasarnya pesantren jiwanya adalah kemasyarakatan.

Sekolah Islam dalam wujud SDIT/SMPIT/SMAIT pada awalnya mengalami kesulitan. Akan tetapi mereka memiliki kelebihan dalam jaringan, etos kerja dan tata kelola organisasi yang lebih baik. Meskipun swasta, tetapi ditangani oleh guru-guru muda dengan semangat kerja yang tinggi. Yang mereka tunjukkan adalah layanan pendidikan yang dapat menjawab kebutuhan peserta didik kekinian. Hasil kerja mereka inilah yang mampu menarik perhatian masyarakat dan akhirnya memercayakan anak-anak mereka untuk sekolah di SDIT/SMPIT/SMAIT.

Perguruan tinggi Islam yang dekat dengan masyarakat Kelurahan Bungguosu adalah IAIN Kendari, Universitas Muhammadiyah Kendari, dan STAI Rawa Aopa. Namun kecenderungan orang tua adalah ke IAIN Kendari yang telah mengalami perkembangan pesat setelah beralih status. 


\section{Pembahasan}

\section{A. Pentingnya adaptasi teknologi terbaru bagi Lembaga Pendidikan Islam}

Tantangan lembaga pendidikan Islam (madrasah, pesantren, sekolah Islam, dan perguruan tinggi Islam) semakin kompleks. Secara internal persekolahan Islam harus melakukan perbaikan secara terus menerus untuk menghasilkan mutu yang baik. Pengelolaan lembaga pendidikan berbasis ilmiah (scientific management) harus dijemput untuk melahirkan terobosan-terobosan baru yang relevan dengan kebutuhan masyarakat (Syahrul, 2013). Implikasi cara pandang ini adalah kemauan warga sekolah untuk melakukan adaptasi terhadap perkembangan teknologi terbaru.

Era industry 4.0 yang baru saja dimasuki umat manusia sedunia mesti menjadi tantangan dalam pengelolaan lembaga pendidikan Islam. Tradisi lama harus mulai ditinggalkan untuk dapat hidup sesuai tuntutan zaman yang serba digital. Persekolahan Islam sudah mesti memulai mengembangkan pelayanan sekolah berbasis teknologi internet. Merintis website sekolah perlu dilakukan, tidak hanya ikut-ikutan trend, tetapi dimanfaatkan sebesar-besarnya untuk pengelolaan sekolah yang efektif dan efisien (Laugi, 2018). Pemanfaatan website sekolah tidak hanya untuk menunjukkan profil sekolah sebagaimana disaksikan saat ini, tetapi dapat menjadi tempat penyimpanan data dalam skala besar yang sewaktu-waktu dapat digunakan untuk pengambilan kebijakan organisasi (Akib at al, 2020). Bagi pemimpin sekolah, website sekolah dapat dikembangkan sebagai sistem informasi manajemen untuk membantu mereka dalam melakukan pengawasan dan pengendalian (Syahrul, at al, 2019). Tidak hanya sisi manajerial yang mendapatkan berkah akibat kemajuan teknologi informasi ini. Jika dikembangkan dengan baik, maka proses pembelajaran yang merupakan core business sekolah dapat memanfaatkan keberadaan website sekolah untuk kegiatan pembelajaran, misalnya E-learning (Samrin \& Syahrul, 2021).

Pemanfaatan teknologi internet dalam pengelolaan sekolah dapat menampilkan wajah baru lembaga pendidikan Islam, tidak lagi sebagai lembaga yang mendapat stigma ukhrowi oriented. Tampilan ini dapat menjadi cara marketing yang baik dalam menarik perhatian masyarakat, juga merubah sikap umum masyarakat yang kurang menyukai lembaga pendidikan Islam. 


\section{B. Perbaikan Praktik Kepemimpinan pada Lembaga Pendidikan Islam}

Perbaikan kualitas secara berkelanjutan dan upaya adaptasi teknologi terbaru, sebagaimana dikemukakan di atas, mesti dimulai dari seorang pemimpin. Fungsi seorang pimpinan sekolah tidak hanya sebagai manajer, lebih dari itu dia harus memainkan peran sebagai leader. Para leader inilah yang akan tampil mewarnai perkembangan lembaga pendidikan, terutama membuat perbedaan (Nanus \& Dobbs, 1999). Pada lembaga pendidikan Islam, para pemimpinnya mesti dapat menggali nilai-nilai kepemimpinan dari ajaran Islam yang bersifat progresif, yang membawa lembaga mereka memperoleh kemajuan (Marham, 2016).

Kepemimpinan yang diharapkan di tengah kompetisi persekolahan yang sangat ketat adalah kepemimpinan perubahan, yaitu model kepemimpinan kepeloporan, yang menentukan hitam putih lembaga pendidikan Islam. Kepemimpinan model ini memiliki mental yang kuat dalam menghadapi tantangan zaman, memiliki visi, dan terbukan terhadap inovasi. Salah satu praktik kepemimpinan ini dapat ditemukan dalam tradisi PM Gontor yang didasarkan pada 14 kualifikasi (Syahrul, 2015). Meskipun kuat, tetapi model kepemimpinan yang dikembangkan Gontor tetap memerhatikan sisisisi humanis warga pondok. Karenanya, proses pemberdayaan (empowering) adalah salah satu fokus pendidikan dalam pengelolaan PM Gontor (Suryadi \& Syahrul, 2021). Meskipun, diskursus empowering leadershing ini masih menjadi perdebatan karena tidak selalu efektif untuk menghasilkan kinerja yang tinggi. Sehingga disarankan untuk melihat konteks ketika menerapkan empowering leadership (Cheong at al, 2019).

\section{Memulai Menerapkan Perencanaan Strategis pada Lembaga Pendidikan Islam}

Salah satu elemen penting dalam pembentukan organisasi adalah tujuan bersama, dimana tujuan itu tidak dapat dicapai jika dilakukan secara individidual (Robbins, 1983). Tujuan organisasi dapat dibedakan menjadi tiga bagian, yaitu: jangka pendek, jangka menengah, dan jangka panjang. Penetapan tujuan jangka pendek dan menengah adalah dalam rangka mencapai tujuan jangka panjang. Dalam konteks inilah pembicaraan tentang perencanaan strategis dimulai, dimana pimpinan lembaga pendidikan Islam mesti membuat desain besar pengembangan sekolah. Rencana strategis adalah 
penghubung antara realitas pelanggan (masyarakat) dengan berbagai kegiatan sekolah (Syahrul, at al, 2017).

Era informasi dan teknologi saat ini menghadirkan banyak ketidakpastian, sehingga perencanaan strategis dapat menjadi kerangka besar dalam mengantisipasi segala bentuk ketidakpastian itu (Syahrul, 2015). Ketajaman seorang pemimpin dituntut untuk dapat memimpin lembaga pendidikan Islam pada masa-masa krisis. Ia menunjukkan kepekaan yang tinggi terhadap berbagai kelemahan lembaganya, dan memahami tantangan yang sedang dihadapi (Sastramayani \& Badarwan, 2019). Pada organisasi bisnis, pengetahuan tentang kepemimpinan krisis telah menjadi tuntutan. Para eksekutif perusahaan yang menempuh pendidikan pada sekolah bisnis menekan kepemimpinan krisis sebagai program inti dalam kurikulum mereka. Hal ini disebabkan oleh peningkatan frekuensi dan risiko tinggi yang diakibatkan oleh krisis (Hertelendy at al, 2021). Dalam kondisi yang tidak menentu, pemimpin lembaga pendidikan Islam mesti menyadari bahwa setiap saat adalah krisis, sehingga selalu antisipatif terhadap berbagai perkembangan.

\section{Peningkatan Akreditasi Lembaga Pendidikan Islam}

Akreditasi sekolah adalah gambaran komprehensif tentang pengelolaan sekolah. Melalui mekanisme pengukuran dan penilaian yang dilakukan oleh assessor, suatu sekolah akan memperoleh skor yang menunjukkan peringkat akreditasinya. Aspek-aspek yang diukur dalam akreditasi sekolah didasarkan pada ruang lingkup standard nasional pendidikan (SNP), mencakup: 1) standard isi; 2) standar proses; 3) standard kompetensi lulusan; 4) standar pendidik dan tenaga pendidikan; 5) standard sarana prasana; 6) standard pengelolaan sekolah; 7) standard pembiayaan; 8) standard penilaian pendidikan (Nasional, 2005).

Pengelolaan lembaga pendidikan Islam harus diarahkan untuk memenuhi 8 standar nasional pendidikan. Patut diketahui bahwa standar nasional ini bersifat minimal, artinya ada tantangan bagi lembaga pendidikan Islam untuk menyelenggarakan pendidikan yang lebih tinggi, melampaui standar nasional pendidikan. Beberapa sekolah saat ini telah merintis menjadi sekolah bertaraf internasional, yang berarti adanya upaya untuk membuat loncatan melampaui akreditasi nasional, menuju akreditasi internasional (Fattah at al, 2009). Secara faktual akreditasi lembaga pendidikan Islam masih tertinggal dari sekolah-sekolah umum, sehingga perhatian para 
pimpinan sekolah mesti tertuju pada perbaikan akreditasi. Peningkatan akreditasi menjadi salah satu faktor penentu pilihan orang tua dalam menyekolahkan anak-anak mereka.

\section{Kesimpulan dan Saran}

Persepsi masyarakat terhadap lembaga pendidikan Islam sangat beragam. Hal ini didasari oleh sikap, motivasi, dan harapan mereka pada lembaga pendidikan Islam. Rendahnya kepercayaan masyarakat pada lembaga pendidikan Islam adalah menunjukkan sikap mereka yang lebih menyukai lembaga pendidikan umum. Pemilihan lembaga pendidikan Islam masih didasari oleh faktor ekonomi, agama, dan keluarga. Harapan orang tua yang menyekolahkan anak pada lembaga pendidikan Islam lebih pada aspek religious, moral, dan pembentukan karakter. Oleh karenanya, orang tua memiliki kecenderungan lebih besar memilih sekolah umum.

Implikasi dari kajian ini penulis mengajukan saran-saran sebagai berikut : 1) perlunya adaptasi teknologi terbaru pada lembaga pendidikan Islam; 2) perbaikan praktik kepemimpinan pada lembaga pendidikan Islam; 3) memulai menerapkan perencanaan strategis pada lembaga pendidikan Islam; dan 4) peningkatan akreditas. 


\section{Daftar Pustaka}

Akib, A., Karno, E., Erdiyanti, E., Syahrul, S., Badarwan, B., \& Murniati, M. (2020, April). The use of SIMPEG-based data mining techniques in measuring employee performance in Islamic higher education. In IOP Conference Series: Materials Science and Engineering (Vol. 830, No. 3, p. 032013). IOP Publishing.

Alim, N., Badarwan, B., \& Syahrul, S. (2020). Edukasi Kepemimpinan Berbasis Tradisi Lokal pada Masyarakat Tolaki di Kabupaten Konawe. Shautut Tarbiyah, 26(1), 32-49.

Cheong, M., Yammarino, F. J., Dionne, S. D., Spain, S. M., \& Tsai, C. Y. (2019). A review of the effectiveness of empowering leadership. The Leadership Quarterly, 30(1), 34-58.

Creswell, J. W., \& Poth, C. N. (2016). Qualitative inquiry and research design: Choosing among five approaches. Sage publications.

Dedih, U., Zakiyah, Q. Y., \& Melina, J. O. (2019). Perhatian orang tua dalam pendidikan keagamaan anak di rumah hubungannya dengan perilaku mereka di lingkungan sekolah. Atthulab: Islamic Religion Teaching and Learning Journal, 4(1), 1-19.

Erdiyanti, E. (2018). Fenomena Orang Tua dalam Memilih Lembaga Pendidikan Islam (Studi Pada MIS Pesantren Ummushabri Kendari). Shautut Tarbiyah, 23(2), 15-34.

Fattah, N., Hartati, T., \& Mulyasari, E. (2009). Manajemen Sekolah Bertaraf Internasional. Jurnal Educationist, 3(1).

Hertelendy, A. J., McNulty, E., Mitchell, C., Gutberg, J., Lassar, W., Durneva, P., \& Rapp, D. (2021). Crisis leadership: The new imperative for MBA curricula. The International Journal of Management Education, 19(3), 100534.

https://id.wikipedia.org/wiki/Kabupaten_Konawe\#: :text=Berdasarka n\%20data\%20Kementerian\%20Dalam\%20Negeri\%20tahun\% 202020\%2C\%20jumlah,jiwa\%20\%282\%2C07\%25\%29\%20da n\%20Katolik\%20sebanyak\%201.117\%20jiwa\%20\%280\%2C4 $3 \% 25 \% 29$.

Isnaini, F., \& Shobahiya, M. (2017). EKSPEKTASI DAN MOTIVASI ORANG TUA MENYEKOLAHKAN ANAK DI SMA MUHAMMADIYAH 1 SURAKARTA KELAS XI TAHUN 
PELAJARAN 2016/2017 (Doctoral dissertation, UNIVERSITAS MUHAMMADIYAH SURAKARTA).

Laugi, S. (2018). Sistem Informasi berbasis Web dalam Penyelenggaran Lembaga Pendidikan. Shautut Tarbiyah, 24(1), 109-126.

Marham, S. (2016). Kepemimpinan Religio-Transformasional: Altruisme Kiai dalam Membangun Karakter dan Budaya Organisasi di PM Gontor VII Sulawesi Tenggara. Laporan Penelitin LPPM IAIN Kendari.

Melamba, B. (2013). Tolaki: sejarah, identitas, dan kebudayaan. Penerbit Lukita.

Miles, M. B., \& Huberman, A. M. (1994). Qualitative data analysis: An expanded sourcebook. sage.

Nanus, B., \& Dobbs, S. M. (1999). Leaders who make a difference: Essential strategies for meeting the nonprofit challenge.

Nasional, D. P. (2005). Peraturan Pemerintah Nomor 19 Tahun 2005. Tentang Standar Nasional Pendidikan.

Robbins, S. P. (1983). Organization theory: The structure and design of organizations. Prentice-Hall.

Sabdah, S., \& Sastramayani, S. (2018). Menjaga Tradisi Islam Orang Tolaki melalui Pengenalan Al Qur'an pada Masyarakat di Kelurahan Bungguosu, Konawe. Shautut Tarbiyah, 24(1), 91108.

Samrin, M. P. I., \& Syahrul, S. P. I. (2021). Pengelolaan Pengajaran. Deepublish.

Sastramayani, S., \& Badarwan, B. (2019). Kepemimpinan Krisis dalam Pengelolaan Sekolah. Shautut Tarbiyah, 25(2), 181-201. Sonaru, Yahya, Wawancara, Baruga, 2015.

Suryadi, S., \& Syahrul, S. (2021). Determining the Direction of the Pesantren (Empowering Leadership Practice at PM Gontor 6 Putera, Southeast Sulawesi). Shautut Tarbiyah, 27(1), 59-76.

Syahrul, S. (2017). Tanggung Jawab Sosial Pesantren: Studi pada Pondok Pesantren Al Munawwarah Pondidaha, Konawe. Shautut Tarbiyah, 23(2), 120-134.

Syahrul, S. (2013). Penelitian sebagai Instrumen Perbaikan Kualitas Kinerja Organisasi Pendidikan secara Berkelanjutan (Continuous Improvement). Al-TA'DIB: Jurnal Kajian Ilmu Kependidikan, 6(1), 150-163. 
Syahrul, S., Alim, N., Pairin, P., \& Nur, J. (2019). Utilization of management information systems in managerial supervision at IAIN Kendari. International Journal of Recent Technology and Engineering (TM), 8(1C2), 392-392.

Syahrul, S. (2015). Kepemimpinan dan Inovasi Lembaga Pendidikan (Pengalaman Pondok Gontor VII Putra Sulawesi Tenggara). Al-TA'DIB: Jurnal Kajian Ilmu Kependidikan, 8(1), 82-100.

Syahrul, S., Karno, E., \& Badarwan, B. (2017). Social Responsibility of University: Bridging Moslim Reality in Strategic Plan of IAIN Kendari, Southeast Celebes, Indonesia.

Syahrul, S. (2015). Mengelola Perguruan Tinggi dalam Iklim Ketidakpastian (Memahami Dinamika Perencanaan Strategis di STAIN Sultan Qaimuddin Kendari). Al-Izzah: Jurnal HasilHasil Penelitian, 10(1), 143-160.

Vitasari, H. N. (2017). Motivasi Orang Tua Menyekolahkan Anak di Sekolah Berbasis Islam (Studi Kasus di Desa Singosari Mojosongo Boyolali) (Doctoral dissertation, IAIN SALATIGA). 